\title{
Effect of DNA extraction methods on the detection of porcine ingredients in halal cosmetics using real-time PCR
}

\author{
Yu Song Kim ${ }^{1} \cdot$ Hee Kyung Yü $\mathbf{H}^{1}$ Beom Zoo Lee ${ }^{1,2}$. \\ Kwang Won Hong ${ }^{1}$ (D)
}

Received: 6 June 2018/ Accepted: 20 July 2018/Published online: 30 July 2018

(C) The Korean Society for Applied Biological Chemistry 2018

\begin{abstract}
In recent years, halal cosmetics have attracted considerable attention worldwide. We developed a realtime PCR assay based on the mitochondrial gene $n d h 5$ for rapid detection of porcine ingredients in halal cosmetic products. We also compared several DNA extraction methods for the most efficient approach in different types of cosmetics. Porcine template DNA was spiked into three types of cosmetics (liquid-type and powder-type mask packs, and cream) and extracted with five commercial DNA extraction kits and the CTAB method. The extraction efficiency of each method was evaluated by determining the detection limits of real-time PCR assay. The lowest detection limit of real-time PCR for each cosmetic product was as follows: $2.28 \times 10^{0}$ copies for liquid-type mask pack when the Power Prep ${ }^{\mathrm{TM}}$ DNA extraction kit and TIANamp Genomic DNA kit were used, $2.28 \times 10^{1}$ copies for powder-type mask pack when QIAamp DNA stool mini kit and the Power Prep ${ }^{\mathrm{TM}}$ DNA extraction kit were used, and $2.28 \times 10^{\circ}$ copies for cream when the Power Prep ${ }^{\mathrm{TM}}$ DNA extraction kit was used. The pig-specific real-time PCR assay facilitated the detection of trace amounts of the template DNA in cosmetics, and an appropriate DNA extraction method was used depending on the type of cosmetics.
\end{abstract}

Kwang Won Hong

hkwon@dongguk.edu

1 Department of Food Science and Biotechnology, College of Life Science and Biotechnology, Dongguk University, Goyang-si 10326, Republic of Korea

2 Chemland Co., Ltd, Gunpo IT Valley B-1405, Gosan-ro 148-gil, Gunpo-si, Gyeonggi-do, Republic of Korea
Keywords DNA extraction methods - Halal cosmetics · Pig · Real-time PCR

\section{Introduction}

With the increase in Muslim population, halal industries are growing rapidly. Halal means 'allowed' according to Islamic law; conversely, haram means 'forbidden' [1]. Therefore, haram elements derived from sources such as pig, dog, animal blood, alcohol, etc., are forbidden during the manufacture of halal products [2]. Currently, halal food is the largest proportion in the global halal market, and cosmetics, medicines, fashion, and tourism are also emerging as major sectors [1]. In particular, the halal cosmetics market is estimated at $\$ 56$ billion in 2015 , accounting for $7 \%$ of the global cosmetics market. The halal cosmetics market is expected to reach $\$ 81$ billion by 2021 [3].

Halal certification is required for a product to enter the halal market. Each product must go through a strict qualification process to ensure that it does not contain any haram elements [4]. Various analytical methods can be used to identify haram elements in halal products. In the case of halal foods, electric nose, gas chromatography, HPLC, NMR spectroscopy, and polymerase chain reaction (PCR) are used to detect hidden animal ingredients such as fats and proteins derived from pig [5-9]. In a few cosmetics, ingredients derived from pigs such as fatty acids, glycerin, and collagen are used in the production of body lotions, creams, and mask packs. As mentioned above, the method of detection of haram components in halal foods may be applicable to halal cosmetics. However, it is not well known. 
In general, the detection of specific components in the final product may be limited depending on the analytical method used, as the various components can be modified or degraded by thermal, physical, or chemical treatment during the manufacture. DNA is a relatively stable material for a variety of physical and chemical treatments during the food manufacturing process. Biological extracts added to food or cosmetics are usually not purified to a very high degree due to the high cost involved, and the products are likely to be contaminated with the species-specific DNA.

PCR is a rapid, accurate, and highly sensitive method that can selectively amplify a small amount of target DNA present in a product using species-specific primers [10-12]. In addition, real-time PCR (rt-PCR) is faster, more sensitive, more accurate, and quantitative when compared with PCR because of the additional fluorescent probe [13-15]. Therefore, the rt-PCR method appears to be effective for the detection of pig components in cosmetics. Although PCR is a reliable analytical method, its results can be influenced by the quality of the DNA used [16]. DNA quality is a critical factor in PCR because PCR inhibitors such as metal ions, polysaccharides, polyphenols, and detergents, which may be present in the sample, can affect the amplification of target DNA [17, 18]. Therefore, the preferred DNA extraction method should be simple and rapid and minimize PCR inhibition [19]. Although several studies have compared the efficiency of DNA extraction from a variety of foods [20-22], few studies have examined the efficiency of DNA extraction kits used in the cosmetics industry.

Among the different types of cosmetics, the demand for mask packs, which can be used for cleansing and moisturizing, is increasing worldwide. In addition, cream is one of the basic cosmetic products with a high demand. Therefore, in this study, we developed a pig-specific rtPCR assay to detect porcine DNA in halal cosmetics. We also compared the performance of various DNA extraction methods by measuring the detection limit of rt-PCR.

\section{Materials and methods}

\section{Meats, vegetables, bacterial strains, and cosmetic samples}

Pork (Sus scrofa domesticus), other meats (chicken, cow, deer, dog, duck, goat, horse, and sheep), and vegetables (carrot, ginger, lettuce, peanut, potato, spinach, soybean, rice, and wheat) used in this study were purchased from local supermarkets in Seoul, Korea. Other meats except pork, vegetables and bacterial strains (Escherichia coli, Bacillus cereus, Salmonella enterica, and Staphylococcus aureus) were used as the PCR-negative controls. Cosmetic samples (cream, liquid-type and powder-type mask packs) were obtained from a cosmetic company (Chemland, Gunpo-si, Korea). In addition, several halal-certified and general cosmetics were purchased from a departmental store in Seoul, Korea for field tests.

\section{Chromosomal DNA isolation}

Chromosomal DNAs were purified from meat and vegetable samples (about $100 \mathrm{mg}$ ) using a Power Prep ${ }^{\mathrm{TM}}$ DNA extraction from food and feed kit (Kogenebiotech, Seoul, Korea) according to the manufacturer's instructions as briefly described below. A crushed sample (about $100 \mathrm{mg}$ ) was lysed with $400 \mu \mathrm{L}$ of Lysis buffer A and $40 \mu \mathrm{L}$ of buffer B for $1 \mathrm{~h}$ at $65{ }^{\circ} \mathrm{C}$, followed by chloroform extraction. The sample was centrifuged at $12,000 \mathrm{rpm}$ for $10 \mathrm{~min}$. The supernatant was mixed with $200 \mu \mathrm{L}$ of Binding buffer and $200 \mu \mathrm{L}$ of isopropanol. The sample mixture was passed through the column, followed by two washes with $75 \% \mathrm{EtOH}$. The DNA was eluted with $100 \mu \mathrm{L}$ of sterilized distilled water, and the appropriate amount of DNA was used for PCR amplification. All bacterial strains were grown in $5 \mathrm{~mL}$ of Luria-Bertani broth at $37{ }^{\circ} \mathrm{C}$. The bacterial DNA was isolated from $5 \mathrm{~mL}$ of overnight cultures using the same DNA extraction kit. Purified DNA was recovered in $50-100 \mu \mathrm{L}$ of sterilized distilled water.

\section{Primer and probe design}

The primers and probe used are shown in Table 1. The $n d h 5$ gene of mitochondrial DNA (GenBank accession number AP003428.1) was used to design pig-specific primers and probe. Comparison of the nucleotide sequences of mitochondrial $n d h 5$ genes available in the GenBank was used to design the Sus2 and Sus NDH5 primer sets. The PCR amplification of porcine chromosomal DNA with the Sus2 primer set yielded a 403-bp DNA fragment, which was used as porcine template DNA in all spiking experiments. Further, the Sus NDH5 primer set was designed to amplify a 139-bp DNA fragment from the 403-bp template DNA for the detection of porcine DNA in cosmetics. The $5^{\prime}$ and $3^{\prime}$ ends of the TaqMan probe were labeled with 6-carboxyfluorescein and black hole quencher 1, respectively.

\section{Porcine template DNA preparation}

A 403-bp porcine template DNA was amplified by PCR from porcine chromosomal DNA with the Sus2 primer set. Amplified DNA fragments were recovered from agarose gel using the PCR clean-up gel extraction kit. The concentration of the purified template DNA was $50 \mathrm{ng} / \mu \mathrm{L}$ measured with UV spectrophotometry. The copy number 
Table 1 Oligonucleotide sequences of primers and probe

\begin{tabular}{lll}
\hline Primer name & Nucleotide sequence & Amplicon size (bp) \\
\hline Sus2 & F: CCC ATT CGC CTC ACT CAC A & 403 \\
& R: GTT GTT GGC GGT TAC GAG GA & \\
Sus NDH5 & F: GCC TCA CTC ACA TTA ACC ACA CT & 139 \\
& R: AGG GGA CTA GGC TGA GAG TGA A & \\
& Probe: GGC GTA GGA TAY CCT CGT TTT TAC GT & \\
\hline
\end{tabular}

of the template DNA was $2.28 \times 10^{11}$ copies $/ \mu \mathrm{L}$ when calculated using Whelan's formula [23].

\section{DNA extraction from spiked cosmetic samples}

The CTAB method and five commercial DNA extraction kits [Nucleo spin food kit (Macherey-Nagal, Germany), Power Prep ${ }^{\mathrm{TM}}$ DNA extraction from food and feed kit (KogeneBiotech), QIAamp DNA stool mini kit (Qiagen, Hilden, Germany), TIANamp Genomic DNA kit (Tiangen Biotech, Beijing, China), and Wizard Genomic DNA purification kit (Promega, Madison, WI, USA)] were used to extract the spiked porcine template DNA from cosmetic samples. After mixing $90 \mu \mathrm{L}$ of cosmetic sample with 10 $\mu \mathrm{L}$ of diluted template DNA, the DNA was extracted using six different methods. All DNA extractions from the spiked samples were carried out according to the manufacturer's instructions. Each purified DNA sample was recovered in $50 \mu \mathrm{L}$ of sterilized distilled water.

\section{PCR and real-time PCR}

PCR was conducted with aliquots of $25 \mu \mathrm{L}$, each containing $1 \mu \mathrm{L}$ of chromosomal DNA, $2.5 \mu \mathrm{L}$ of $10 \times$ Taq buffer, $0.5 \mu \mathrm{L}$ of dNTP stock solution (containing $10 \mathrm{mM}$ of each dNTP), $0.125 \mu \mathrm{L}$ of Taq polymerase (SolGent Co., Daejeon, Korea), 10 pmol of each primer, and deionized water. The PCR was conducted using a StepOnePlus RealTime PCR System (Applied Biosystems, Foster City, CA, USA) with the following program: 40 cycles of $30 \mathrm{~s}$ at $95{ }^{\circ} \mathrm{C}, 30 \mathrm{~s}$ at $60{ }^{\circ} \mathrm{C}$, and $30 \mathrm{~s}$ at $72{ }^{\circ} \mathrm{C}$, followed by $5 \mathrm{~min}$ at $72{ }^{\circ} \mathrm{C}$. The PCR product $(5 \mu \mathrm{L})$ was loaded on a $1.5 \%$ agarose gel containing ethidium bromide and visualized under UV illumination.

Real-time PCR was carried out with aliquots of $20 \mu \mathrm{L}$, each containing $1 \mu \mathrm{L}$ of template DNA, $10 \mu \mathrm{L}$ of $2 \times$ TaqMan Master Mix, 10 pmol of each primer, $2.5 \mathrm{pmol}$ of the probe, and deionized water. The real-time PCR was run on StepOnePlus Real-Time PCR System with the following program: 1 cycle of $2 \mathrm{~min}$ at $50{ }^{\circ} \mathrm{C}$ and $10 \mathrm{~min}$ at $95{ }^{\circ} \mathrm{C}, 50$ cycles of $15 \mathrm{~s}$ at $95^{\circ} \mathrm{C}$, and $90 \mathrm{~s}$ at $60{ }^{\circ} \mathrm{C}$. The standard curve for porcine DNA was generated with known copies of the template DNA ranging from $2.28 \times 10^{0}$ copies/tube to $2.28 \times 10^{10}$ copies/tube. The threshold cycle $(\mathrm{Ct})$ values were plotted against the corresponding 10-fold serial dilutions of the template DNA. All PCRs and real-time PCRs were conducted in triplicate.

\section{Results and discussion}

\section{Specificity of the pig-specific real-time PCR}

Mitochondrial DNA has been widely used to identify species because of its high copy number in animal cells and well-conserved nucleotide sequence [24, 25]. In this study, the mitochondrial $n d h 5$ gene encoding NADH dehydrogenase subunit 5 was selected as a target for porcine DNA detection based on the nucleotide sequence differences of the mitochondrial $n d h 5$ genes with other animals (data not shown).

To investigate the specificity of the Sus NDH5 primer set for mitochondrial $n d h 5$ gene of pig compared with eight other meats, nine vegetables, and four bacterial strains, rtPCR was performed in triplicate using chromosomal DNA isolated from each sample. No fluorescent signals were observed in the tested samples except pig DNA even after 40 cycles (Table 2). This result indicates that the pigspecific rt-PCR assay facilitates the detection of pig ingredients in halal cosmetics.

\section{Detection limit of the real-time PCR assay}

Real-time PCR is widely used to detect and quantify trace amounts of DNA within complex food products [26-28]. To determine the copy number of porcine template DNA that can be detected by rt-PCR, a standard curve was prepared using tenfold serially diluted DNA, ranging from $2.28 \times 10^{10}$ copies/tube to $2.28 \times 10^{0}$ copies/tube (Fig. 1). The correlation coefficient $\left(R^{2}\right)$ demonstrated the high linearity of the standard curve (Fig. 1A). The $\mathrm{Ct}$ value was 39.95 at $2.28 \times 10^{0}$ copies, the smallest amount of template DNA. Generally, a high threshold cycle $(\mathrm{Ct})$ value may be considered as false-positive because of amplification or fluorescence artifacts during real-time amplification [29]. To confirm whether this $\mathrm{Ct}$ value was valid, agarose gel electrophoresis was performed to determine the formation of the correct amplicon. As shown in Fig. 1B, the 
Table 2 Pig-specific real-time PCR of non-target DNAs

\begin{tabular}{|c|c|c|}
\hline \multicolumn{2}{|l|}{ Samples } & \multirow{2}{*}{$\frac{\mathrm{PCR}}{20.46 \pm 0.52}$} \\
\hline Animals & Pig (positive control) & \\
\hline & Cow & No $\mathrm{Ct}$ \\
\hline & Chicken & No Ct \\
\hline & Sheep & No Ct \\
\hline & Duck & No Ct \\
\hline & Horse & No Ct \\
\hline & Dog & No Ct \\
\hline & Deer & No Ct \\
\hline & Goat & No $\mathrm{Ct}$ \\
\hline \multirow[t]{9}{*}{ Plants } & Potato & No Ct \\
\hline & Lettuce & No $\mathrm{Ct}$ \\
\hline & Spinach & No $\mathrm{Ct}$ \\
\hline & Peanut & No $\mathrm{Ct}$ \\
\hline & Soybean & No $\mathrm{Ct}$ \\
\hline & Carrot & No $\mathrm{Ct}$ \\
\hline & Ginger & No $\mathrm{Ct}$ \\
\hline & Rice & No $\mathrm{Ct}$ \\
\hline & Wheat & No $\mathrm{Ct}$ \\
\hline \multirow[t]{4}{*}{ Bacteria } & Escherichia coli ATCC 27325 & No $\mathrm{Ct}$ \\
\hline & Bacillus cereus ATCC 21772 & No $\mathrm{Ct}$ \\
\hline & Staphylococcus aureus ATCC25923 & No $\mathrm{Ct}$ \\
\hline & Salmonella enterica ACTC13314 & No Ct \\
\hline
\end{tabular}

${ }^{\mathrm{a}}$ The threshold cycle $(\mathrm{Ct})$ values are the mean $\pm \mathrm{SD}$ of three independent experiments

139-bp DNA fragment was amplified, and rt-PCR allowed the detection of the template DNA as low as $2.28 \times 10^{0}$ copies.

\section{Effect of DNA extraction methods on real-time PCR amplification of the spiked porcine DNA}

Various ingredients such as alcohols, fats, pectin, and detergents, which may be present in cosmetics, may

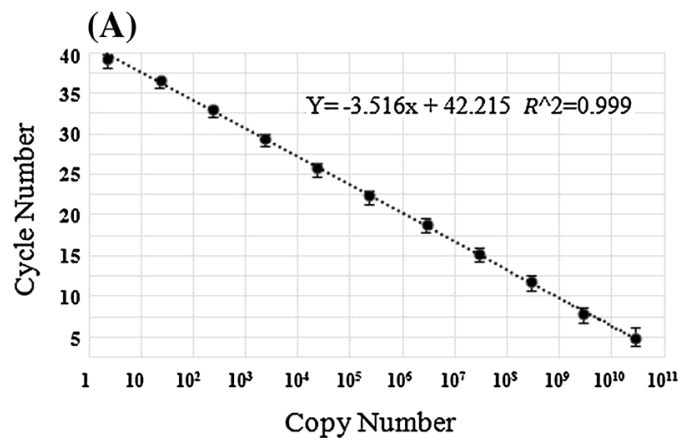

Fig. 1 (A) Standard curve generated by real-time PCR using known amounts of template DNA and (B) agarose gel electrophoresis of realtime PCR products. Real-time PCR was performed with serially diluted (tenfold) template DNA ranging from $2.28 \times 10^{10}$ copies/tube to $2.28 \times 10^{10}$ copies/tube. Negative template control consisted of

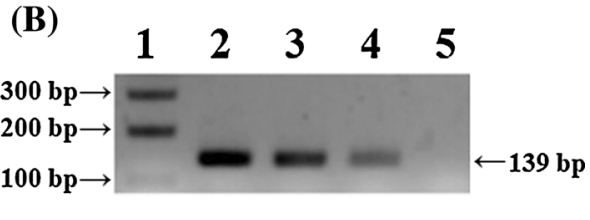

interfere with PCR [30-33]. Therefore, it is crucial to select the appropriate DNA extraction method to exclude these PCR inhibitors. Although a suitable DNA extraction method and extraction efficiency for cosmetics are not well known, the differences in extraction efficiency depend on the type of food. The CTAB method has demonstrated high extraction efficiency for chocolates and biscuit products [16], whereas the Nucleo spin food kit has high extraction efficiency for protein-rich foods such as soybean flour [21]. In addition, the QIAamp DNA stool mini kit is highly efficient for extracting DNA from vegetative oil [22].

In this study, the porcine template DNA was extracted from spiked cosmetic samples (cream, liquid-type mask pack, and powder-type mask pack) using six different methods, and rt-PCR was used to determine the detection limit corresponding to each extraction method. Initially, to detect porcine DNA in the cosmetics before spiking, DNA was extracted from liquid-type mask pack, powder-type mask pack, and cream using the Power Prep ${ }^{\mathrm{TM}}$ DNA extraction kit. Real-time PCR was conducted using the Sus NDH5 primer set and probe for each extracted DNA. Realtime PCR results showed that porcine DNA was not present in the three cosmetics tested (data not shown).

The three cosmetics were artificially spiked with stepwise diluted porcine template DNA, and the DNA was extracted using six different DNA extraction methods. To compare the detection limits of the assay for cosmetics, rtPCR was performed on spiked porcine DNA extracted from three types of cosmetics using six different methods (Table 3). For liquid-type mask pack, rt-PCR enabled detection of the template DNA as low as $2.28 \times 10^{\circ}$ copies using the Power Prep ${ }^{\text {TM }}$ DNA extraction kit and TIANamp Genomic DNA kit, with Ct values of 38.51 and 38.71, respectively. The rt-PCR sensitivity of the Power Prep ${ }^{\mathrm{TM}}$ DNA extraction kit and TIANamp Genomic DNA Kit was 10-100 times greater than that of other extraction methods. For powder-type mask pack, rt-PCR detected DNA as low

the reaction mixture without template DNA. Lane 1: 100-bp ladder. Lanes 2, 3, and 4: samples containing template DNA $\left(2.28 \times 10^{2}\right.$, $2.28 \times 10^{1}$, and $2.28 \times 10^{0}$ copies/tube, respectively). Lane 5: negative template control 
Table 3 Detection limits of real-time PCR assay for spiked porcine DNA in cosmetic samples

\begin{tabular}{|c|c|c|c|c|c|c|}
\hline \multirow[t]{2}{*}{ Cosmetics } & \multirow[t]{2}{*}{ Extraction methods } & \multicolumn{5}{|c|}{ Threshold cycle $(\mathrm{Ct})$} \\
\hline & & $\begin{array}{l}2.28 \times 10^{4} \\
(\text { copies/tube) }\end{array}$ & $\begin{array}{l}2.28 \times 10^{3} \\
(\text { copies/tube })\end{array}$ & $\begin{array}{l}2.28 \times 10^{2} \\
(\text { copies/tube })\end{array}$ & $\begin{array}{l}2.28 \times 10^{1} \\
(\text { copies/tube })\end{array}$ & $\begin{array}{l}2.28 \times 10^{0} \\
(\text { copies/tube) }\end{array}$ \\
\hline \multirow{6}{*}{$\begin{array}{l}\text { Liquid-type } \\
\text { mask pack }\end{array}$} & CTAB & $27.34 \pm 0.60^{\mathrm{a}}$ & $31.18 \pm 0.55$ & $35.06 \pm 0.21$ & No $\mathrm{Ct}$ & No $\mathrm{Ct}$ \\
\hline & $\begin{array}{l}\text { Power Prep }{ }^{\mathrm{TM}} \text { DNA } \\
\text { extraction kit }\end{array}$ & $24.28 \pm 0.19$ & $27.44 \pm 0.39$ & $30.97 \pm 0.15$ & $35.21 \pm 0.21$ & $38.51 \pm 0.30$ \\
\hline & $\begin{array}{l}\text { QIAamp DNA stool mini } \\
\text { kit }\end{array}$ & $26.16 \pm 0.16$ & $30.49 \pm 0.56$ & $34.06 \pm 0.15$ & $38.37 \pm 0.23$ & No $\mathrm{Ct}$ \\
\hline & $\begin{array}{l}\text { Wizard genomic DNA } \\
\text { purification kit }\end{array}$ & $30.56 \pm 0.47$ & $33.64 \pm 0.33$ & $37.76 \pm 0.79$ & No Ct & No $\mathrm{Ct}$ \\
\hline & $\begin{array}{l}\text { TIANamp genomic DNA } \\
\text { Kit }\end{array}$ & $24.99 \pm 0.21$ & $28.19 \pm 0.11$ & $32.07 \pm 0.41$ & $35.77 \pm 0.49$ & $38.71 \pm 0.61$ \\
\hline & Nucleo spin food kit & $27.19 \pm 0.21$ & $31.00 \pm 0.11$ & $35.22 \pm 0.24$ & $38.94 \pm 0.21$ & No Ct \\
\hline \multirow{6}{*}{$\begin{array}{l}\text { Powder-type } \\
\text { mask pack }\end{array}$} & CTAB & $30.11 \pm 0.11$ & $33.86 \pm 0.17$ & $38.13 \pm 0.14$ & No Ct & No $\mathrm{Ct}$ \\
\hline & $\begin{array}{l}\text { Power Prep }{ }^{\mathrm{TM}} \text { DNA } \\
\text { extraction kit }\end{array}$ & $27.56 \pm 0.24$ & $31.94 \pm 0.08$ & $35.48 \pm 0.37$ & $39.07 \pm 0.09$ & No Ct \\
\hline & $\begin{array}{l}\text { QIAamp DNA stool mini } \\
\text { kit }\end{array}$ & $26.63 \pm 0.50$ & $29.75 \pm 0.67$ & $34.14 \pm 0.86$ & $37.63 \pm 0.97$ & No $\mathrm{Ct}$ \\
\hline & $\begin{array}{l}\text { Wizard genomic DNA } \\
\text { purification Kit }\end{array}$ & $34.14 \pm 0.34$ & $38.75 \pm 0.40$ & $\mathrm{No} C t$ & No Ct & No $\mathrm{Ct}$ \\
\hline & $\begin{array}{l}\text { TIANamp genomic DNA } \\
\text { Kit }\end{array}$ & $30.59 \pm 1.28$ & $34.04 \pm 1.26$ & $38.42 \pm 1.56$ & No Ct & No $\mathrm{Ct}$ \\
\hline & Nucleo spin food kit & $30.40 \pm 0.68$ & $33.67 \pm 0.22$ & $36.73 \pm 0.34$ & No Ct & No $\mathrm{Ct}$ \\
\hline \multirow[t]{6}{*}{ Cream } & CTAB & $30.57 \pm 0.72$ & $34.69 \pm 0.09$ & $38.52 \pm 0.52$ & No Ct & No $\mathrm{Ct}$ \\
\hline & $\begin{array}{l}\text { Power Prep }{ }^{\mathrm{TM}} \text { DNA } \\
\text { extraction kit }\end{array}$ & $26.41 \pm 0.28$ & $30.16 \pm 0.23$ & $34.03 \pm 0.27$ & $36.78 \pm 0.34$ & $39.07 \pm 0.07$ \\
\hline & $\begin{array}{l}\text { QIAamp DNA stool mini } \\
\text { kit }\end{array}$ & $30.97 \pm 0.70$ & $34.35 \pm 1.22$ & $\mathrm{No} C t$ & No Ct & No $\mathrm{Ct}$ \\
\hline & $\begin{array}{l}\text { Wizard genomic DNA } \\
\text { purification Kit }\end{array}$ & $29.96 \pm 0.16$ & $34.44 \pm 0.38$ & $38.7 \pm 0.33$ & No Ct & No $\mathrm{Ct}$ \\
\hline & $\begin{array}{l}\text { TIANamp Genomic DNA } \\
\text { Kit }\end{array}$ & $29.52 \pm 0.98$ & $33.50 \pm 1.20$ & $38.47 \pm 1.12$ & No Ct & No $\mathrm{Ct}$ \\
\hline & Nucleo spin food kit & $29.02 \pm 0.09$ & $33.15 \pm 0.20$ & $36.8 \pm 0.33$ & No Ct & No $\mathrm{Ct}$ \\
\hline
\end{tabular}

${ }^{\mathrm{a}}$ The threshold cycle $(\mathrm{Ct})$ values are the mean $\pm \mathrm{SD}$ of three independent experiments

as $2.28 \times 10^{1}$ copies using the QIAamp DNA stool mini kit and Power Prep ${ }^{\mathrm{TM}}$ DNA extraction kit, with $\mathrm{Ct}$ values of 37.63 and 39.07, respectively. The rt-PCR detection limit for both kits was 10-100 times higher than the other extraction methods. In the case of cream, rt-PCR detected DNA as low as $2.28 \times 10^{0}$ copies with the Power Prep ${ }^{\text {TM }}$ DNA extraction kit alone, and the $\mathrm{Ct}$ value was 39.07. The rt-PCR detection limit for the Power Prep ${ }^{\mathrm{TM}}$ DNA extraction kit was 100-1000 times higher than the other extraction methods. Cream is mainly composed of lipids such as oils or waxes [34, 35]. Hexane or chloroform treatment minimizes PCR inhibition during DNA extraction from lipid-rich cosmetics [36, 37]. However, the use of organic solvents in the extraction process is tedious and cumbersome; thus, most commercial kits do not use organic solvents. Therefore, the Power Prep ${ }^{\mathrm{TM}}$ DNA extraction kit, which uses chloroform during DNA extraction process, may produce optimal results in rt-PCR assays.

\section{Testing of halal cosmetics}

In order to detect the presence of pig-derived ingredients in commercial halal cosmetics, six types of halal cosmetics and nine types of general cosmetics (five liquid-type mask packs, five powder-type mask packs, and five creams) were tested. Furthermore, real-time PCR assay was performed using DNA extracted from each cosmetic product with the Power Prep ${ }^{\mathrm{TM}}$ DNA extraction kit (Table 4). All of the 15 products tested by rt-PCR were negative, indicating the absence of porcine DNA. 
Table 4 Field test of halal cosmetics using real-time PCR assay

\begin{tabular}{lll}
\hline Cosmetics & Sample number & Threshold cycle $(\mathrm{Ct})$ \\
\hline Liquid-type mask packs & $1^{\mathrm{a}}, 2^{\mathrm{a}}, 3^{\mathrm{a}}, 4$, and 5 & No Ct \\
Powder-type mask packs & $1,2,3,4$, and 5 & $\mathrm{No} \mathrm{Ct}$ \\
Cream & $1,2,3,4$, and 5 & $\mathrm{No} \mathrm{Ct}$ \\
Positive control $\left(2.28 \times 10^{6}\right.$ copies/tube $)$ & & 19.11 \\
No template control & & No Ct \\
\hline
\end{tabular}

${ }^{\mathrm{a}}$ Cosmetic products were certified by Jabatan Kemajuan Islam Malaysia (JAKIM)
In summary, the real-time PCR assay based on the mitochondrial gene $n d h 5$ facilitated the detection of trace amounts of the porcine template DNA in cosmetics. This study also showed that the extraction of porcine DNA from cosmetics may depend on the type of cosmetics. Overall, the Power Prep ${ }^{\mathrm{TM}}$ DNA extraction kit was the most suitable for isolation of DNA from the tested cosmetics. This pig-specific real-time PCR assay was also applicable for the detection of hidden porcine ingredients in food products or identification of food fraud.

Acknowledgments This work was performed as a research project (315052-3) of the Korea Institute of Planning and Evaluation for Technology of Food, Agriculture, Forestry and Fisheries supported by the Ministry of Agriculture, Food and Rural Affairs.

\section{References}

1. Yusuf AH, Shukor SA, Bustamam USA (2016) Halal certification vs business growth of food industry in Malaysia. JOEBM 4(3):247-251

2. Nakyinsige K, Man YBC, Sazili AQ (2012) Halal authenticity issue in meat and meat products. Meat Sci 91:207-214

3. Thomson Reuters (2016) State of the global Islamic economy report 2016/2017 (2016) 159-167

4. Mukherjee SR (2014) Global halal: meat, money, and religion. Religions 5:22-75

5. Nurjuliana M, Man YBC, Hashim DM (2011) Analysis of lard's aroma by an electronic nose for rapid halal authentication. J AOCS 88:75-82

6. Nurjuliana M, Man YBC, Hashim DM, Mohamed AKS (2011) Rapid identification of pork for halal authentication using the electronic nose and gas chromatography mass spectrometer with headspace analyzer. Meat Sci 88:638-644

7. AI-Rashood KA, Abdel-Moety EM, Rauf A (1995) Triacylglycerols-profiling by high performance liquid chromatography: a tool for detection of pork fat (lard) in processed foods. J Liq Chromatogr 18:2661-2673

8. Bargen VC, Brockmeyer J, Humpf HU (2014) Meat authentication: a new HPLC-MS/MS based method for the fast and sensitive detection of horse and pork in highly processed food. J Agric Food Chem 62:9428-9435

9. Siciliano C, Belsito E, De Marco R (2013) Quantitative determination of fatty acid chain composition in pork meat products by high resolution ${ }^{1} \mathrm{H}-\mathrm{NMR}$ spectroscopy. Food Chem 136:546-554

10. Gachet E, Martin GG, Vigneau FG (1998) Detection of genetically modified organisms (GMOs) by PCR: a brief review of methodologies available. Trends Food Sci Technol 9:380-388
11. Engel KH, Moreano F, Ehlert A (2006) Quantification of DNA from genetically modified organisms in composite and processed foods. Trends Food Sci Technol 17:490-497

12. Holst-jensen A, Ronning SB, Lovseth A, Berdal KG (2003) PCR technology for screening and quantification of genetically modified organism (GMOs). Anal Bioanal Chem 375(8):985-993

13. Yang C, Jiang Y, Zhu C, Yin Y, Huang K (2003) Application of real-time PCR for quantitative detection of campylobacter jejuni in poultry, milk, and environment water. FEMS Immunol Med Microbiol 38(3):265-271

14. Daum LT, Barnes WJ, McAvin JC, Neidert MS, Cooper LA, Huff WB, Gaul L, Riggins WS, Morris S, Salmen A, Lohman KL (2002) Real-time PCR detection of Salmonella in suspect foods from a gastroenteritis outbreak in Kerr County, Texas. J Clin Microbiol 40(8):3050-3052

15. Bernard PS, Lay MJ, Wittwer CT (1998) Integrated amplification and detection of the C677T point mutation in the methylenetetrahydrofolate reductase gene by fluorescence resonance energy transfer and probe melting curves. Anal Biochem 255(1):101-107

16. Gryson N, Messens K, Dewettinck K (2004) Evaluation and optimization of five different extraction methods for soy DNA in chocolate and biscuits. Extraction of DNA as a first step in GMO analysis. J Sci Food Agric 84(11):1357-1363

17. Smith DS, Maxwell PW (2007) Use of quantitative PCR to evaluate several methods for extracting DNA form corn flour and cornstarch. Food Control 18(3):236-242

18. Schrader C, Schielke A, Ellerbroek L, Johne R (2012) PCR inhibitors-occurrence, properties and removal. J Appl Microbiol 113:1014-1026

19. Smith DS, Maxwell PW, De Bohr SH (2005) Comparison of several methods for extracting DNA from potatoes and potatoderived products. J Agric Food Chem 53(26):9848-9859

20. Pirondini A, Bonas U, Maestri E, Marmiroli M, Marmiroli N, Visioli G (2010) Yield and amplificability of different DNA extraction procedures for traceability in the dairy food chain. Food Control 21(5):663-668

21. Mafra I, Silva SA, Ferreira de Silva CS, Beatriz M, Oliveira PP, Moreira EJMO (2008) Comparative study of DNA extraction methods for soybean derived food products. Food Control 19(12):1183-1190

22. Testolin R, Lain O (2005) DNA extraction form olive oil and PCR amplification of microsatellite markers. J Food Sci 70(1):108-112

23. Whelan JA, Russell NB, Whelan MA (2003) A method for the absolute quantification of cDNA using real-time PCR. J Immunol Methods 278:261-269

24. Partis L, Croan D, Guo Z, Clark R, Coldham T, Murby J (2000) Evaluation of a DNA fingerprinting method for determining the species origin of meats. Meat Sci 54:369-376

25. Girish PS, Anjaneyulu ASR, Viswas KN, Shivakumar BM, Anand M, Patel M (2005) Meat species identification by polymerase chain reaction-restriction fragment length polymorphism 
(PCR-RFLP) of mitochondrial 12S rRNA gene. Meat Sci 70:107-112

26. García A, Madrid R, García T, Martín R, González I (2017) Detection of food allergens by Taqman real-time PCR methodology. Methods Mol Biol 1592:95-108

27. Kesmen Z, Yetiman AE, Şahin F, Yetim H (2012) Detection of chicken and turkey meat in meat mixtures by using real-time PCR assays. J Food Sci 77:167-173

28. Marino AM, Percipalle M, Giunta RP, Salvaggio A, Caracappa G, Alfonzetti T (2017) Development and validation of a real-time PCR assay for the detection of Toxoplasma gondii DNA in animal and meat samples. J Vet Diagn Invest 29:203-207

29. Caraguel CGB, Stryhn H, Gagné N, Dohoo Ian R, Hammell KL (2011) Selection of a cutoff value for real-time polymerase chain reaction results to fit a diagnostic purpose: analytical and epidemiologic approaches. J Vet Diagn Invest 23(1):2-15

30. Ku JE, Han HS, Song JH (2013) The recent trend of the national preservation used in cosmetics. Korean $\mathrm{J}$ Aesthet Cosmetol 11(5):835-844

31. Ann YG, Kim SK, Shin CS, Min JH (2002) Inhibitory effect of wax gourd extract on melanin formation and acne-forming bacterial growth. Korean J Food Nutr 15:137-143

32. Demeke T, Jenkins GR (2010) Influence of DNA extraction methods, PCR inhibitors and quantification methods on real-time
PCR assay of biotechnology-derived traits. Anal Bioanal Chem 396:1977-1990

33. Rossen L, Nørskov P, Holmstrom K, Rasmussen OF (1992) Inhibition of PCR by components of food samples, microbial diagnostic assays and DNA-extraction solutions. Int $\mathrm{J}$ Food Microbiol 17(1):37-45

34. Kwon HN, Yoo IS, Jeong H, Kim KS, Kim ES, Lee JS, Kim OK (2014) Evaluation of the stability of five basic creams containing Curcumae longae Radix extract. J Korean Soc Beauty Art 15(1):155-165

35. Lee SJ, Kim SM, Kim MK (2011) A study on of the application sculpture materials utilizing cosmetics ingredients (petroleum jelly, micro-crystalline wax, stearic acid). Korean J Aesthet Cosmetol 9(2):53-63

36. Terry CF, Harris N, Parkes HC (2002) Detection of genetically modified crops and their derivatives: critical steps in sample preparation and extraction. J AOAC Int 85(3):768-774

37. Hubbard WD, Sheppard AJ, Newkirk DR, Prosser AR, Osgood TO (1977) Comparison of various methods for the extraction of total lipids, fatty acids, cholesterol and other sterols from food products. J AOCS 54(2):81-83 